\title{
Contribuição à crítica da 'economia solidária'
}

\author{
Henrique André Ramos Wellen \\ Universidade Federal do Rio de Janeiro (UFRJ)
}

\section{Contribuição à crítica da 'economia solidária'}

Resumo: Neste ensaio, procura-se problematizar algumas premissas sobre a 'economia solidária' a partir de dois movimentos centrais: a transmutação do valor de troca em solidariedade e a transformação de qualidades solidárias em mercadorias. O primeiro ponto remete ao fato da 'economia solidária' preconizar o uso do capital como uma escolha individual, promovendo uma visão mistificadora da atual fase do capitalismo. Nesta perspectiva, as vontades das pessoas são tratadas como independentes das determinações do capital, apelando-se a elas para que façam uso solidário do seu capital particular e ampliem, dessa forma, o projeto em questão. Posteriormente, com base em leitura crítica da tese de que essas organizações dispõem de autênticas qualidades subjetivas e que estas representam vantagens competitivas frente às empresas capitalistas, aponta-se para a mistificação do uso da solidariedade como diferencial competitivo. Essas posturas são tratadas como formas ideológicas e enganosas que servem para intensificar processos de alienação humana Palavras-chave: economia solidária, ideologia, alienação, marxismo, comunidade.

\section{Contribution to a Criticism of 'Solidarity Economics'}

Abstract: This essay analyzes some concepts about 'solidarity economics' based on two principal movements: the transmutation of exchange value into solidarity and the transformation of solidarity into a commodity. The first point relates to the fact that 'solidarity economics' sees the use of capital as an individual choice, promoting a mystifying vision of the current phase of capitalism. From this perspective, individual will is treated as independent of the determinations of capital. Appeals are made to individuals to use their private capital in a solidarity manner and thus expand the project in question. Based on a critical reading of the thesis that these organizations have authentic subjective qualities that represent competitive advantages in relation to capitalist companies, the mystification of the use of solidarity as a competitive distinction is indicated. These positions are considered to be ideological and misleading forms that serve to intensify human alienation.

Key words: solidarity economics, ideology, alienation, Marxism, community. 


\section{Introdução}

Definida como um "conjunto de atividades econômicas - de produção, distribuição, consumo e crédito - organizadas e realizadas solidariamente por trabalhadores e trabalhadoras sob a forma coletiva e autogestionária" (SENAES, 2006, p. 11), a 'economia solidária' ${ }^{1}$ representa atualmente um movimento econômico e social de significante amplitude. Os dados apontam para a sua relevância: em quase metade das cidades brasileiras existem experiências que a integram. Em pesquisa realizada em 2005, "foram identificadas cerca de 14.954 empreendimentos econômicos solidários em 2.274 municípios do Brasil (o que corresponde a $41 \%$ dos municípios brasileiros)" (SENAES, 2006, p. 15). Trata-se, portanto, de uma experiência socialmente importante na fase atual do capitalismo, o que torna relevante um estudo mais aprofundado de seus principais postulados.

Para Singer (2002, p. 09-10), a cooperativa de produção representa o protótipo da empresa solidária, uma vez que nessa organização, "todos os sócios têm a mesma parcela de capital e, por decorrência, o mesmo direito de voto em todas as decisões." $\mathrm{Na}$ visão desse autor, a definição dessa experiência não se limita, no entanto, ao espaço interno da organização, mas abarca toda a estrutura social: a "economia solidária é outro modo de produção, cujos princípios básicos são a propriedade coletiva ou associada do capital e o direito à liberdade individual."

Além de significar "uma resposta importante dos trabalhadores e das comunidades pobres em relação às transformações ocorridas no mundo do trabalho" (SENAES, 2006, p. 07), conforme advoga o Ministro do Trabalho e do Emprego do Brasil, Luiz Marinho, o papel da 'economia solidária' seria o de superar o modo de produção capitalista, implantando no seu lugar um novo ordenamento social. Na visão de seus defensores, a 'economia solidária' poderá, gradativamente, superar o capitalismo, tendo como início de sua atuação os interstícios isentos das determinações do capital.

$\mathrm{O}$ objetivo central desse texto refere-se à problematização de algumas das principais premissas presentes em obras sobre a 'economia solidária', à luz de categorias extraídas da análise crítica da realidade do sistema capitalista. Trataremos, em especial, de dois movimentos centrais que, a nosso ver, estruturam as teses da 'economia solidária': a transmutação do valor de troca em solidariedade e a transformação de qualidades solidárias em mercadorias.

Conforme veremos a seguir, o primeiro ponto de destaque de nossa análise crítica das teses da 'economia solidária' remete ao fato desse projeto preconizar o uso do capital como uma escolha individual. Para tanto, seus autores promovem uma visão mistificadora da atual fase do capitalismo, tratando as vontades humanas como independentes das determinações do capital. Esse recurso serve ideologicamente para justificar que o capital não representaria uma força ativa na totalidade social, mas que seria induzido de acordo com a subjetividade de cada um dos seus portadores. Com a vigência dessa pseudo-realidade, os representantes desse projeto apelam para a boa vontade das pessoas, para que essas façam um uso solidário do seu capital particular e ampliem, dessa forma, a 'economia solidária'.

Em momento complementar ${ }^{2}$, apontaremos para a mistificação do uso da solidariedade como diferencial competitivo a serviço dessas organizações, a partir de uma leitura crítica da visão de que - por causa do seu peculiar trato aos trabalhadores e clientes - as mesmas dispõem de autênticas qualidades subjetivas e que estas representam vantagens competitivas frente às empresas capitalistas. Trataremos essas posturas como formas ideológicas e mistificadoras que servem para intensificar processos de alienação humana.

\section{O valor de troca como solidariedade}

Uma das idéias presentes nas propostas da 'economia solidária' é a da competição ser vantajosa para ambas as partes da relação comercial por permitir, ao mesmo tempo, "a todos nós consumidores escolher o que mais nos satisfaz pelo menor preço", a concorrência também pode possibilitar "que o melhor vença, uma vez que as empresas que mais vendem são as que mais lucram e mais crescem, ao passo que as que menos vendem dão prejuízo e se não conseguirem mais clientes acabarão por fechar" (SINGER, 2002, p. 7).

Já o mercado representaria o espaço propício para a realização da liberdade humana, no qual cada indivíduo poderia efetivar suas escolhas de acordo com sua subjetividade: "o indivíduo tem o direito de tomar uma iniciativa, abrir uma empresa ou vender o fruto do seu trabalho. O mercado não é um mal, ele é uma forma de realização individual" (SINGER, 1998, p. 113). Seria, portanto, o local privilegiado para se colocar em prática a iniciativa de cada um. Conforme afirma Singer (1998, p. 113), o "mercado de trabalho ${ }^{3}$ é condição de liberdade humana e alguns mercados de bens e de serviços me parecem igualmente essenciais, porque uma das liberdades interessantes é a de iniciativa."

No entanto, segundo autores da 'economia solidária', apesar de representarem elementos positivos para toda a sociedade, tanto a competição quanto a sua efetivação pela instância do mercado possuem qualidades que precisariam ser obstruídas. Isso se deve ao fato de que a existência das desigualdades imanentes ao sistema capitalista teria a sua fonte nas diferenças particulares, historicamente construídas, visto que, en- 
quanto uns conseguiram acumular capital, outros apenas alcançaram maiores prejuízos ${ }^{4}$. Ou seja,

[...] enquanto os primeiros acumulam capital, galgam posições e avançam nas carreiras, os últimos acumulam dívidas pelas quais devem pagar juros cada vez maiores, são despedidos ou ficam desempregados até que se tornam 'inempregáveis', o que significa que as derrotas os marcaram tanto que ninguém mais quer empregá-los. Vantagens e desvantagens são legadas de pais para filhos e para netos. Os descendentes dos que acumularam capital ou prestígio profissional, artístico etc, entram na competição econômica com nítida vantagem em relação aos descendentes dos que se arruinaram, empobreceram e foram socialmente excluídos. O que acaba produzindo sociedades profundamente desiguais (SINGER, 2002, p. 8-9).

As diferenças sociais provenientes de ações particulares promoveriam a tal ponto as desigualdades sociais, que estas se tornariam pilares para as contradições sociais entre perdedores e ganhadores. Para o autor é esse o fato que "explica porque o capitalismo produz desigualdade crescente, verdadeira polarização entre ganhadores e perdedores" (SINGER, 2002, p. 8).

Apesar da necessidade do mercado como local de afirmação dos interesses individuais, seria preciso a imposição de limites sociais para regular as desigualdades sociais ${ }^{5}$. A diferença entre o sistema socialista e o sistema capitalista encontrar-se-ia nessa forma de regular a sociedade: enquanto o primeiro permitiria a existência de grandes diferenças entre vantagens e desvantagens sociais, o outro instauraria instituições para combatê-las. A peculiaridade do socialismo estaria, para Singer, presente na adição de uma qualidade imprescindível: a tentativa de amenização das desigualdades sociais.

Após o livre funcionamento do mercado, entraria em ação uma instituição para redistribuir as vantagens: "o que o socialismo tem a mais é que, depois que o jogo do mercado é feito, depois que os ganhadores e os perdedores estão definidos, deve existir uma instituição que tira uma grande parte dos bens materiais dos ganhadores e dá para os perdedores" (SINGER, 1998, p. 114). O socialismo, nesse entendimento, representaria a manutenção não apenas do mercado, mas também do Estado, isto é, muito mais um sinônimo de keynesianismo, do que de socialismo como fase de transição para o comunismo.

Ao analisarmos de forma crítica essa tese que estrutura a proposta da 'economia solidária', podemos perceber que, por trás dessa crítica romântica ao sistema capitalista, permanecem alguns fortes resquícios de sua legitimação. Ao definir o uso individual feito do capital aqui como a causa central das desigualdades sociais, aparece como pano de fundo a idéia de que o capital tem o seu destino determinado pelo uso particular. O capital, de acordo com esse pensamento, aparece não como dominante, mas como dominado; não como uma força social que gera determinações, mas condicionado pelo emprego feito pelas pessoas, o que, no extremo, induz a uma análise moralista ou valorativa da sociedade. Isto significaria a utilização particular feita do capital, e não as determinações da universalidade da lógica do capital, que configurariam a sociedade ${ }^{6}$.

A defesa da competição e do mercado como uma entidade necessária, mesmo estando ligada à denúncia da desvantagem social proveniente das diferenças sociais acumuladas, nega a discussão central do próprio capital como uma força social, como causa geradora dessas desigualdades, sendo sua proposta de fornecimento de vantagens para quem não as tem uma forma de legitimação dessa mesma força social, não tocando, portanto na causa do problema. A idéia "de que o mercado é essencial ao socialismo" (SINGER, 1998, p. 113), estabelece-se, nesse sentido, negando aquilo que é próprio da especificidade do mercado em sua concretude capitalista: o lócus privilegiado de atuação das forças do capital, tanto de aquisição de força de trabalho quanto de realização de mais-valia.

A mistificação promovida pelos representantes da 'economia solidária' tem sua gênese no processo de manipulação e desvirtuamento da essência da realidade atual. Essa visão aparece desprovida de grande parte das determinações provenientes do capitalismo moderno, apreendendo a fase atual do capitalismo pela imagem de capitalismo embrionário. Não se leva em conta que, no capitalismo moderno, o valor de troca deixa de ser um meio das relações de troca para tornar-se uma meta suprema; fazendo surgir o capitalista como a figura do capital personalizado. Em outras palavras, omite-se que:

\section{O conteúdo objetivo daquela circulação - a valori- zação do valor - é sua meta subjetiva, e só enquanto a apropriação crescente da riqueza abstrata é o úni- co motivo indutor de suas operações, ele funciona como capitalista ou capital personificado, dotado de vontade e consciência (MARX, 1985, p. 129).}

Como consequiência dessa apreensão superficial da realidade, apresenta-se, dentro das premissas da 'economia solidária', a possibilidade de que as organizações integrantes desse projeto se localizem num espaço alheio ao domínio do capital, ou seja, nos interstícios do sistema capitalista ${ }^{7}$. No entender de Singer (2002, p. 88), o cooperativismo, apesar de situar-se nos interstícios do sistema capitalista, consegue realizar um papel importante de obstrução à ampliação do domínio do capital: se "o cooperativismo desempenhou e desempenha um papel de freio à 
centralização do capital ao menos num setor, ele não passa de um modo de produção intersticial nas formações capitalistas."

A superficialidade dessa tese está em crer que alguma parte da sociedade, por mais isolada que seja, vai estar ausente das determinações capitalistas e, por isso, pode ser passível de não ser vista como área de promissora lucratividade. Para demonstrar tal mistificação, remetemo-nos às palavras de Paulo Netto (2005, p. 38-39), quando este afirma que, a partir da fase imperialista do capitalismo, surge uma tendência de apropriação de todos complexos sociais pela lógica da mercantilização:

\begin{abstract}
Na idade do imperialismo, a organização monopólica da vida social tende a preencher todos os interstícios da vida pública e da vida privada; a subordinação ao movimento do capital deixa de ter como limites imediatos os territórios da produção: a tendência manipuladora e controladora que lhe é própria desborda os campos que até então ocupara (no capitalismo concorrencial), domina estrategicamente a circulação e o consumo e articula uma indução comportamental para penetrar a totalidade da existência dos agentes sociais particulares.
\end{abstract}

Com o marco desse novo contexto histórico, não apenas os setores diretamente ligados à produção capitalista são aprisionados pelo interesse do capital, mas também as demais esferas sociais: "O monopólio, uma vez que foi constituído e controla milhares de milhões, penetra de maneira absolutamente inevitável em 'todos' os aspectos da vida social, independentemente do regime político e de qualquer outra "particularidade", (LÊNIN, 1986, p. 618). Essa é uma das diferenças que distingue a fase monopolista ou imperialista do capitalismo de sua fase embrionária, concorrencial $^{9}$.

Ao defender a existência dos 'interstícios do capitalismo', teríamos que advogar também um retorno à sua fase concorrencial. Para a permanência de um intervalo social entre as partes dominadas do capital, seria necessário que o capital, coerentemente, ainda não tivesse entrado na fase monopolista, e que não tivesse interesse imediato na mercantilização da totalidade social. Em nosso entendimento, o fator central presente na defesa da existência dos interstícios do capitalismo é que, por meio da aceitação desse artifício, promova-se uma representação ideal que não reflita as especificidades da fase atual do capitalismo. A idéia de interstício dentro do capitalismo nos conduz a visualizar a sociedade atual como constituída por meio de setores ou partes possuidoras de altos níveis de autonomia ${ }^{10}$. Sob este prisma, limitam-se as relações de interdependência entre as diversas esferas da sociedade capitalista madura, atribuindo a estas uma posição de autonomia que não lhes é peculiar. Confunde-se aquilo que é referente às sociedades pré-capitalistas, com o que é exclusivo e fundamental da organização econômica capitalista:

\begin{abstract}
Essa situação de fato tem seu fundamento na diferença profunda entre a organização econômica do capitalismo e a das sociedades pré-capitalistas. A diferença muito surpreendente que mais nos importa agora é que toda sociedade pré-capitalista forma uma unidade incomparavelmente menos 'coerente', do ponto de vista econômico, do que a capitalista. Na primeira, a autonomia das partes é muito maior, e suas interdependências econômicas são muito mais limitadas e menos desenvolvidas do que no capitalismo. Quanto mais frágil o papel da circulação das mercadorias na vida da sociedade como um todo, quanto mais cada uma das partes da sociedade vive praticamente em autarquia econômica (comunas aldeãs) ou não desempenha nenhum papel na vida propriamente econômica da sociedade e no processo de produção em geral (como era o caso de importantes frações de cidadãos nas vilas gregas e em Roma), tanto menos a forma unitária, a coesão organizacional da sociedade e do Estado, têm fundamento real na vida real da sociedade (LUKÁCS, 2003, p. 149).
\end{abstract}

As determinações que são provenientes dessa nova fase do capitalismo provocam impactos diretos na estrutura das organizações da 'economia solidária', o que faz surgir a necessidade de repensar as relações dessas organizações com o mercado. Antigos axiomas precisam ser repensados à luz destas novas configurações societárias. Esse é o caso, por exemplo, da premissa de que "a grande vantagem inicial das cooperativas era o 'mercado assegurado' por um quadro de sócios em plena expansão" proveniente do fato de que, com base na associação de consumidores e com o uso de fundos emprestados, era possível "concentrar a atividade distributiva que lhe confere superioridade competitiva em relação ao comércio preexistente, que na segunda metade do século ainda era pré-capitalista, estando nas mãos de pequenos operadores" (SINGER, 2002, p. 52). 
Ou, ainda, conforme advoga Birchall (apud SINGER, 2002, p. 71), que a vantagem competitiva das organizações de 'economia solidária' perante as empresas capitalistas estaria no fato daquelas possuírem uma relação mais próxima com as comunidades, ou seja, que o "segredo do sucesso do movimento é seu foco primordial em comunidades locais e sua capacidade de reforçar o senso de identidade étnica."

Além disso, a comunidade aparece nas teses da 'economia solidária' como a panacéia da emancipação humana, fazendo com que a relação dialética entre indivíduo e sociedade torne-se fraturada na medida em que se exponencia a importância da autonomia subjetiva na organização social. Quando analisamos a afirmação de que,

O trabalho segundo tais pensamentos desempenharia hoje um papel eminente no reforço das solidariedades colectivas, seria a maneira moderna do viver em comum e da cooperação, permitiria aos indivíduos serem parte activa de uma relação social maior (a relação de trabalho) e, através dela, integrarem-se na comunidade, na sociedade em miniatura que é a empresa (MÉDA apud ROSENFIELD, 2003, p. 21),

percebemos que ocorre um processo de valoração individualizada que singulariza ${ }^{11}$ a incidência do capital sobre a sociedade e, por isso, suspende as possibilidades concretas de transformação social.

É uma mistificação pensar que as relações internas dentro de uma comunidade estão suspensas das determinações do capitalismo e que a 'economia solidária' poderia forjar, de forma independente, um tipo de racionalidade peculiar. Para superar a ideologia capitalista e fazer submergir qualidades autenticamente humanas, é preciso um movimento que abarque a totalidade social e que não se restrinja à comunidade, isto é, que não se limite à posição de que a "racionalidade assenta na comunidade de trabalho [...], a qual funda-se em vínculos de reciprocidade, que diluem as eventualmente rígidas fronteiras entre interesses individuais e coletivos" (VERONESE; GUARESHI, 2005, p. 66).

Por meio dessa análise, identificamos nas teses da 'economia solidária' um elevado grau de voluntarismo que, por sua vez, pode ser relacionado diretamente com uma posição filosófica idealista. Essa perspectiva relega a apreensão da totalidade social em prol de aspectos avulsos: o "idealismo subjetivo, a partir da chamada aprioridade desta ou daquela atitude em face da realidade, cria 'mundos' especialíssimos, isolados um do outro; esta criação aparece, com particular evidência, em Simmel" (LUKÁCS, 1978, p. 160). Com a vigência desse recurso, a perspectiva de universalidade é desmerecida e o que resulta da análise teórica da realidade são representações falsas ou distorcidas.
Se esse ingrediente já estava presente nas idéias dos chamados socialistas utópicos durante a vigência da fase concorrencial do capitalismo, após a ascensão da fase imperialista e dos grandes monopólios, os defensores da 'economia solidária' acentuam o apelo para a vontade individualizada. A validade dessa afirmação ocorre pela concepção de que, diferentemente da fase atual do capitalismo, o contexto que influía nas organizações dos socialistas utópicos era bem menos impactante, abrindo maiores possibilidades de sucesso no mercado. O roteiro econômico de superação do sistema capitalista aparecia, aos olhos destes pensadores, como uma conquista gradativa que se iniciava pela esfera da distribuição, passando pela produção e culminando numa cooperativa nacional. Ou seja, "aplicando os princípios dos Pioneiros, eles foram capazes de repetir o mesmo roteiro 'do varejo ao atacado, depois à produção própria e finalmente à criação de uma união cooperativa nacional"' (BIRCHALL apud SINGER, 2002, p. 53).

Enquanto as organizações propostas pelos socialistas utópicos possuíam uma margem de manobra de sobrevivência no mercado, as experiências de 'economia solidária' atuais se defrontam com um quadro muito mais restritivo, consubstanciado pelo crescimento e dominação do capital. Para superar idealmente as determinações imanentes à fase atual do capitalismo, os defensores desse projeto advogam a possibilidade de determinação do sentido do capital pelo seu portador individual. As contradições sociais não teriam sua causa no capital como uma relação social, mas exclusivamente na vontade egoísta do seu portador. Nesse sentido, sendo seu detentor um indivíduo de valores solidários, o capital teria também esse sentido, ou seja, a economia seria solidária.

Entretanto, no mundo real, as organizações da 'economia solidária', para disputarem com as empresas capitalistas as margens de mercado, precisam portar elementos que as tornem também competitivas. Tal fato remete à necessidade destas organizações ampliarem o apelo à solidariedade como diferencial competitivo. Se para aquelas organizações a vantagem competitiva era fato resultante da fase embrionária do capitalismo, para estas o diferencial se faz por meio de um recurso intensificado de qualidades solidárias, transformando-as em valor de troca.

\section{A solidariedade como valor de troca}

Consta nas obras teóricas da 'economia solidária' a tese de que, como essas organizações possuem poucas chances de competir com as empresas capitalistas, devem centrar seus esforços em atender à demanda de mercado formada pela busca de um atendimento sofisticado, agrupada por consumidores especiais por terem uma consciência cidadã. 
Diferentemente das empresas capitalistas que se dirigem a um público massificado ou homogeneizado, a 'economia solidária' deveria dar enfoque aos nichos de mercado dos clientes que buscam algo mais do que apenas o valor de troca das mercadorias, ou seja, que não elegem o local de compra de suas mercadorias apenas pelo atributo preço. Conforme advoga Singer (2002, p. 58),

A massificação dos consumidores é um pressuposto. As vantagens que ele oferece se dirigem a um público homogeneizado, cujas preferências são pautadas pela publicidade dos meios de comunicação de massa. Sempre existem demandas por outro tipo de atendimento, em que o consumidor é cidadão, tem direito a ser ouvido e participar das decisões que o afetam. São estas as demandas que a economia solidária atende melhor que o varejo capitalista.

Esse seria o lema da 'economia solidária': não competir com as mercadorias massificadas das grandes corporações capitalistas, mas proporcionar um tipo de produto ou serviço que tenha outros diferenciais, tais como atendimento personalizado e uma relação mais humana entre a organização e seu cliente. Ficam, no entanto, algumas dúvidas acerca da validade desses requisitos: com este tipo de atendimento, o que está sendo vendido: a mercadoria ou a própria relação social? O que é a mercadoria principal nessa relação de troca: o produto ou a forma como esse produto é elaborado e disponibilizado? A 'economia solidária' produz e vende o quê: mercadorias ou slogans de solidariedade?

Essas perguntas possuem, como pano de fundo, dois problemas decisivos. O primeiro - e de percepção mais aparente - é o aspecto econômico. Como as organizações de 'economia solidária' conseguirão sobreviver no mercado, tendo uma mercadoria com preço mais elevado do que as de seus concorrentes diretos? Quais serão os clientes que terão condições materiais para adquirir esse tipo de mercadorias especial? Eles se aproximam mais da faixa de rendimento da classe dos trabalhadores, que dificilmente terão margem disponível de compra superior à reprodução da sua força de trabalho ou, daqueles que, por se apropriarem privadamente da produção social, possuem riqueza a mais que sua necessidade direta de reprodução social e, por isso, dispõem-se a pagar mais por um atendimento do tipo especial ${ }^{12}$ ? A que classe social a 'economia solidária' quer convencer a tornar-se seu cliente fidelizado: os trabalhadores ou os capitalistas?

Em segundo plano, essa relação 'especial' de compra e venda, traz em si um elemento que, à primeira vista, não é facilmente identificado, mas que é essencial para a manutenção e legitimação da ordem capitalista. Trata-se da relação coisificada entre pessoas, na qual não somente a mercadoria passa a ser tida como possuidora de capacidades humanas, como, dialeticamente, capacidades humanas são vendidas como sendo mercadorias. Fortalece-se o fenômeno da reificação que recebe subsídios dessa forma especial de relação mercantil, na qual o cliente, ao comprar uma mercadoria, por um acréscimo de preço, recebe como bônus certificados de solidariedade e cidadania $^{13}$.

Ao adotar essa postura, a 'economia solidária' se apresenta como um projeto que busca substituir a centralidade do trabalho como fonte de valor da mercadoria por características individuais que lhe seriam peculiares. Para tanto, suscita-se um privilégio aos fatores subjetivos, atribuindo a estes uma força social que em muito extrapola àquela referente na sua validade social. Com esse artifício, organizações de 'economia solidária', orientadas a partir de qualidades como a consciência social, teriam capacidade de sucesso no mercado capitalista: "Objetivos sociais podem substituir a ganância como uma poderosa força motivadora. Se forem bem dirigidas, as empresas orientadas para a consciência social podem se sair muito bem no mercado, competindo com as outras baseadas na ganância" (YUNUS; JOLIS, 2006, p. 264).

A diferença competitiva entre as empresas capitalistas e as organizações da 'economia solidária' poderia ser suprimida, nesse sentido, pela aderência de sentimentos que conduzissem a processos motivacionais de trabalho. Seria, a partir do melhor aproveitamento dessas qualidades subjetivas potencialmente presentes nesses tipos de organizações, que a 'economia solidária' utilizar-se-ia de importantes recursos típicos da fase atual capitalismo: "Tais empreendimentos encontram potencialmente no trabalho coletivo e na motivação dos trabalhadores que os compõem, uma importante fonte de competitividade reconhecida no capitalismo contemporâneo" (TAUILLE; DEBACO, 2002, p. 62). O bom emprego dessas qualidades supostamente imanentes às organizações solidárias, em especial das relações de confiabilidade intrínseca, resultaria numa 'eficiência coletiva':

Na medida em que se desenvolva a confiabilidade intrínseca entre os agentes, uma espécie de 'eficiência coletiva' poderá resultar em 'economias de rede'. Pensando em termos de sucesso e expansão destas redes há quem aponte que, tanto em países avançados como em desenvolvimento, 'clusters de pequenas e médias empresas [...] conquistaram mercados externos com base em sua eficiência coletiva' (TAUILLE, 2001, p. 16).

No lugar da competição ter a sua causa na estrutura produtiva, que incide na totalidade social, essa passaria a ser superada de forma individual. A alter- 
nativa para a superação dessa lógica competitiva darse-ia a partir da redefinição das formas de ver o trabalho; de um novo sentido ao trabalho:

A efetivação destes princípios dependeria, no nosso entendimento, de um processo de redefinição das formas de atribuição de sentido ao trabalho para que os valores da autogestão e da solidariedade possam reconfigurar os modos de subjetivação associados à competitividade, ao modelo de gestão e ao individualismo no capitalismo contemporâneo (NARDI et al., 2006, p. 321-322).

Atribuindo um sentido particular ao seu trabalho, os integrantes da 'economia solidária' podem se imaginar como trabalhadores autônomos quando, na verdade, estão inseridos numa relação direta de exploração. Vendem sua força de trabalho, mas são levados a se ver como imunes e superiores a essa relação de exploração. Percebem-se como autônomos, mesmo estando a serviço de empresas de capital internacional: "nos anos 90, cooperativas cearenses ficaram quase seis meses sem encomendas em função da crise Argentina, país para o qual a empresa parceira destinava parte de sua produção" (LIMA, 2003, p.18), além de que "geralmente a empresa determina a produção, como deve ser organizada, padrões, etc" (LIMA, 2003, p.19). Os integrantes dessas organizações podem não saber, mas o fazem.

Promove-se, portanto, um movimento de mistificação da realidade no momento em que se defende que um importante diferencial competitivo a serviço das organizações de 'economia solidária' seria a capacidade de atribuição de sentido do trabalho como um recurso interno, assim como na caracterização dessa qualidade subjetiva como atributo de valor de troca. Ou seja, além de instaurar uma separação entre o espaço interno das organizações da 'economia solidária' e as determinações do modo de produção capitalista, fomenta-se uma mercantilização dessas qualidades subjetivas. Num primeiro momento, ocorre o processo de autonomização da 'economia solidária’ e, em seguida, as características provenientes dessas organizações são transformadas em diferenciais competitivos frente ao mercado capitalista. Como já afirmamos, uma contradição entre as partes que se completa para fechar um ciclo iniciado com a utilização do capital como solidariedade e finalizado com a transformação da solidariedade em valor de troca.

Auferindo para si a possibilidade de atribuição interna de sentido ao trabalho, a proposta da 'economia solidária' suscita uma ruptura mistificadora com a unidade material entre os diversos trabalhos dentro do modo de produção capitalista. Esse posicionamento teórico nos remete a formas anteriores de organização da produção, nas quais as diferentes formas de trabalho ainda não estavam equiparadas numa só.
Ao equiparar seus produtos de diferentes espécies na troca, como valores, equiparam seus diferentes trabalhos como trabalho humano. Não o sabem, mas o fazem. Por isso, o valor não traz escrito na testa o que ele é. $\mathrm{O}$ valor transforma muito mais cada produto de trabalho em um hieróglifo social. Mais tarde, os homens procuram decifrar o sentido do hieróglifo, descobrir o segredo de seu próprio produto social, pois a determinação dos objetos de uso como valores, assim como a língua, é seu produto social. A tardia descoberta científica, de que os produtos de trabalho, enquanto valores, são apenas expressões materiais do trabalho humano despendido em sua produção, faz época na história do desenvolvimento da humanidade, mas não dissipa, de modo algum, a aparência objetiva das características sociais do trabalho. O que somente vale para esta forma particular de produção, a produção de mercadorias, a saber, o caráter especificamente social dos trabalhos privados, independentes entre si, consiste na sua igualdade como trabalho humano e assume a forma de caráter de valor dos produtos de trabalho, parece àqueles que estão presos às circunstâncias de produção mercantil, antes como depois dessa descoberta, tão definitivo quanto a decomposição cientifica do ar em seus elementos deixa perdurar a forma do ar, enquanto corpo físico (MARX, 1985, p. 72).

O trabalho concreto surgiria como uma vantagem da 'economia solidária' frente às empresas capitalistas, uma vez que, enquanto nestas ocorre o trabalho abstrato, naquelas as pessoas atribuiriam um sentido particular à sua produção. Com a prevalência dessa posição analítica, o processo de superação da reificação social, ou de descoberta do hieróglifo social cunhado nos produtos do trabalho, recebe mais um obstáculo. Com o advento desse ponto de vista, para descobrir o segredo de seu próprio produto social, agora não basta apenas enxergar o trabalho como única fonte de valor, mas, antes disso, superar o sentido individual atribuído ao trabalho, inserindo-o na totalidade social. O processo de reificação também está presente ao tratar não apenas mercadorias como detentoras de subjetividade, mas diferenciando os trabalhadores segundo suas especificidades - como trabalhadores concretos -, o que promove implicações diretas para a consciência de classe ${ }^{14}$.

A transformação social não pode ter como seu núcleo estrutural a premissa de superação subjetiva e particular das determinações materiais presentes no capitalismo, ao contrário disso, faz-se preciso analisar a 'economia solidária' por meio de suas relações de dependência com o mercado. A consciência das pessoas que integram essas organizações não está acima dessas relações, mas é consubstanciada por elas; não está suspensa aos determinantes eco- 
nômicos, nem se sobrepõem a estes. Não existe uma dualidade estrutural entre o espaço interno organizacional e a totalidade social, marcada por uma ruptura da consciência: para aquele, sentimentos de solidariedade, para este, a competição mais selvagem. As regras que governam o funcionamento externo da 'economia solidária' são as mesmas que incidem sobre o seu espaço interno. Conforme aponta Lima (2003, p. 19-20),

\begin{abstract}
Para Quijano (2002), as regras que regem as cooperativas são as do mercado e do salário e o caráter de reciprocidade ou solidariedade operariam externamente às relações de trabalho, a partir da decisão consciente de seus membros. Essa consciência é um processo complexo, pois raramente significa uma situação de materialidade mais satisfatória para seus membros o que explica o desinteresse por esse tipo de empreendimento em momentos de estabilidade e crescimento econômico. $\mathrm{O}$ caráter voluntário da adesão às cooperativas fica comprometido em contextos de crise econômica nos quais as possibilidades de ocupação são reduzidas. Fica a questão se é uma alternativa a exploração capitalista, ou à falta dessa mesma exploração.
\end{abstract}

Dentro desse processo teórico de autonomização da 'economia solidária' e de apresentação de suas características peculiares como diferenciais competitivos, destaca-se a relação dessas organizações com a comunidade local em que está inserida. Conforme observamos anteriormente, a relação com a comunidade surge aos olhos de representantes desse projeto como uma vantagem competitiva perante as empresas capitalistas. Por se estabelecer, majoritariamente, apenas no mercado local, essas organizações teriam mais proximidade com os seus clientes e, por isso, aportariam maiores vendas. Promovendo um 'atendimento especial' a seus clientes, não apenas restrito a uma pura relação mercantil, alcançar-seiam nichos de mercado de pessoas mais conscientes e cidadãs. As qualidades subjetivas que integram esse 'atendimento especial' representam, portanto, uma forma de agregar mais valor ao produto comercia-lizado. Com isso, subjetividade é transformada também em mercadoria. Esse é um exemplo da mercantilização de qualidades subjetivas.
A solidariedade que é apresentada como uma qualidade que distingue essa proposta das empresas capitalistas serve, na verdade, muito mais como valor agregado à publicidade do que representa uma prática concreta. Observamos que, dessa forma, a utilização dessa qualidade como valor de troca é mais utilizada para alcançar maior quantidade de valores de troca do que para efetivar as qualidades subjetivas. A solidariedade passa a ser, nesse sentido, uma mercadoria tal como qualquer outra, usada para agregar valor econômico à empresa.

\section{Considerações finais}

Analisamos algumas teses da 'economia solidária' buscando demonstrar, a partir de um confronto destas com as determinações advindas da realidade atual, sua qualidade mistificadora em dois momentos centrais: no trato do capital como uma entidade individual e no sentido singular atribuído ao trabalho. Inicialmente demonstramos o efeito enganador de advogar que a contradição social do capitalismo tem sua fundação na desigualdade individual, historicamente constituída, e que podem existir partes da sociedade autônomas que não seriam consubstanciadas pelas determinações do capitalismo e, por isso, estariam suscetíveis à influência exclusiva de propostas alternativas limitadas ao escopo da comunidade. Em seguida evidenciamos que o apelo a qualidades supostamente solidárias como diferenciais competitivos para sobrevivência das organizações no mercado capitalista, seja presente na venda de capacidades humanas como mercadorias ou no uso fantasioso de sentido realizador do trabalho nos processos de motivação dos trabalhadores, repercute em novos obstáculos a uma apreensão da totalidade social.

Ao promover a fantasia de uma sociedade resultante de características elegidas da forma que se almeja, a apreensão da realidade presente em autores da 'economia solidária', no lugar de se estabelecer pela diminuição da distância inseparável entre o subjetivo e o objetivo, produz uma suspensão fictícia dessa distância. Desconsidera-se o fato de que o conhecimento "não é a superação da distância entre o subjetivo e o objetivo, mas justamente sua mais plena reprodução: ape- 
nas tendo por mediação essa distância pode o conhecimento se realizar enquanto movimento de constante aproximação da consciência ao ser" (LESSA, 2002, p. 98).

Desta forma, o singular deixa de ser um meio de compreensão das determinações da totalidade social para ser a fonte exclusiva dessa análise mistificadora, como se, nada fosse preciso além de si mesmo; nele estariam localizados a causa e a solução dos problemas sociais. Esse fato é agravado em momentos de decadência ideológica nos quais ocorre em maior quantidade e potência a supervalorização do singular, de modo que isso se torna uma obsessão ou um fetiche: "teoria e práxis da decadência sublinham sempre a singularidade, que se torna um fetiche como unicidade, irrepetibilidade, indissolubilidade etc" (LUKÁCS, 1978, p. 165) ${ }^{15}$.

Tal como acontece com autores que advogam a 'economia solidária', a mistificação presente em análises restritas a aspectos singulares da realidade proporciona um reflexo falso das possibilidades concretas de superação do sistema capitalista, elegendo como regra aquilo que é, na verdade, exceção. Ocorre, dentro desse processo, uma supervalorização do singular a tal ponto deste tornar-se ilusoriamente independente do contexto social que lhe fornece sentido. Como uma proposta que tencione superar a ordem do capital e abolir as causas que a mantêm não pode prescindir de uma apreensão correta das determinações da totalidade social, a perspectiva apresentada na 'economia solidária' se mostra, portanto, não com uma função social revolucionária, mas representa um retrocesso ideológico.

\section{Referências}

GERMER, C. M. A 'economia solidária': uma crítica marxista. Revista Outubro, São Paulo: Alameda, n. 14, p. 193-214, 2006. GUEVARA, C.E.; MANDEL, E.; BETTELHEIM, C. El gran debate: sobre la economia en Cuba. Madrid: Ocean Press, 2005.

IAMAMOTO, M. V. ‘Serviço Social alternativo': elementos para a sua problematização. In: Renovação e conservadorismo no Serviço Social: ensaios críticos. São Paulo: Cortez, 2004. p.17-39.

LÊNIN, V. I. O imperialismo, fase superior do capitalismo. In:_. Obras escolhidas, v.1. São Paulo: Alfa-Omega, 1986.

LESSA, S. Mundo dos homens: trabalho e ser social. São Paulo: Boitempo, 2002.

. Uma 'praga de fantasias'. Revista Praia Vermelha, Rio de Janeiro: UFRJ, v. 10, p. 84-111, 2004.
LIMA, J. C. Cooperativas de produção industrial: autonomia e subordinação do trabalho. In: CASTRO, N. A.; DEDECCA, C. S. (Org.). A ocupação da América Latina: tempos mais duros. São Paulo, Rio de Janeiro: ALAST, 1998. (Série II Congresso Latino-americano de Sociologia do Trabalho).

O trabalho autogestionário em cooperativas de produção. A retomada de um velho paradigma. In: XXVII ENCONTRO ANUAL DA ANPOCS, 2003. Anais... Caxambu:ANPOCS, 2003.

LUKÁCS, G. História e consciência de classe. São Paulo: Martins Fontes, 2003.

Introdução a uma estética marxista. Rio de Janeiro: Civilização Brasileira, 1978.

MARX, K. O Capital: crítica da economia política. São Paulo: Nova Cultural, 1985. V. I, tomos 1 e2, Livro primeiro: o processo de produção do capital.

A miséria da filosofia: resposta à filosofia da miséria de Proudhon. São Paulo: Centauro, 2001.

MONTAÑO, C. Microempresa na era da globalização. São Paulo: Cortez, 1999. (Coleção questões de nossa época, n. 69).

Terceiro setor e questão social: crítica ao padrão emergente de intervenção social. São Paulo: Cortez, 2005.

NARDI, H. C. et al. Subjetividade e solidariedade: a diversidade das formas de implicação dos jovens na economia solidária. Psicologia Reflexão e Crítica, Curso de Pós-Graduação em Psicologia da Universidade Federal do Rio Grande do Sul, v. 19, n. 2, p. 320-328, 2006.

PAULO NETTO, J. Capitalismo monopolista e Serviço Social. São Paulo: Cortez, 2005.

ROSENFIELD, C. L. A autogestão e a nova questão social: repensando a relação indivíduo-sociedade. In: SEMINÁRIO INTERMEDIÁRIO USP DAANPOCS, GT Trabalhadores, Sindicatos e a Nova Questão Social. Anais... São Paulo: USP, 2003.

SENAES - Secretaria Nacional de Economia Solidária. Atlas da economia solidária no Brasil. Brasília: TEM, Senaes, 2006.

SINGER, P. Mercado e Cooperação: um caminho para o socialismo. In: HADDAD, F. (Org.). Desorganizando o consenso: nove entrevistas com intelectuais à esquerda. Petrópolis: Vozes, 1998. 
Introdução à economia solidária. São Paulo: Fundação Perseu Abramo, 2002.

TAUILLE, J. R.; DEBACO, E. S. Autogestão no Brasil: a viabilidade econômica de empresas geridas por trabalhadores. In: VVAA. Economia Solidária, v. 1, 2002.

. Do socialismo de mercado à economia solidária. In: SEMINÁRIO INTERNACIONAL TEORIAS DE DESENVOLVIMENTO NONOVO SÉCULO, 2001. Anais... Rio de Janeiro: UFRJ, 2001. Reprografado.

TAVARES, M. A. Os fios (in)visíveis da produção capitalista: informalidade e precarização do trabalho. São Paulo: Cortez, 2004.

VERONESE, M. V.; GUARESHI, P. Possibilidades solidárias e emancipatórias do trabalho: campo fértil parca da psicologia social crítica. Revista Psicologia \& Sociedade, v. 17, n. 2 , p. $58-69,2005$.

YUNUS, M.; JOLIS, A. O banqueiro dos pobres. São Paulo: Ática, 2006.

\section{Notas}

$1 \mathrm{O}$ uso recorrente deste termo entre aspas justifica-se pela sua elevada carga ideológica, requerendo uma análise crítica que o desmistifique.

2 Faz-se preciso explicitar que a separação entre esses dois momentos tem a função exclusiva de facilitar a compreensão desse texto, ou seja, trata-se de um recurso didático. Dentro da totalidade social, não existe uma separação temporal entre eles, uma vez estão conectados dialeticamente.

3 Ressaltamos que nessa passagem o autor usa os termos "mercado"e "mercado de trabalho" com o mesmo sentido. A falta de precisão e rigor nos termos utilizados é um problema recorrente em suas análises sobre 'economia solidária': 'É preciso alertar para o fato de que os escritos de Singer sobre a 'economia solidária' possuem características que tornam difícil a crítica. Por um lado, o autor não se esforça em precisar os fundamentos teóricos das suas teses e propostas e dos conceitos que utiliza. $\mathrm{O}$ autor faz uso de conceitos marxistas sem se ater ao seu sentido original e sem chamar a atenção do leitor para o sentido alterado que lhes dá. Por outro lado, Singer muda de opinião sobre pontos específicos do tema, de um escrito a outro, sem aparentemente preocupar-se em evitar afirmações contraditórias e, quando incorre nelas, não adverte para a mudança de opinião nem explica os seus motivos"(GERMER, 2006p. 196).

4 Essa posição fica ainda mais clara nas palavras do ganhador do prêmio Nobel da Paz: "Nos Estados Unidos descobri que a economia de mercado liberava o indivíduo e lhe permitia fazer escolhas pessoais. O único inconveniente é que ela favorece os poderosos. Mas eu achava que os pobres deveriam tirar proveito do sistema para melhorar a sua sorte" (YUNUS; JOLIS, 2006, p. 261). Ou seja, lastima-se que o 'único inconveniente' seja o favorecimento dos 'poderosos'.

5 Mesmo numa sociedade estruturada pela 'economia solidária', a desigualdade seria uma realidade insuperável: "Se toda economia fosse solidária, a sociedade seria muito menos desigual. Mas, mesmo que as cooperativas cooperassem entre si, inevitavelmente algumas iriam melhor e outras pior, em função do acaso e das diferenças de habilidades e inclinação das pessoas que as compõem. Haveria, portanto, empresas ganhadoras e perdedoras. Suas vantagens e desvantagens teriam de ser periodicamente igualadas para não se tornarem cumulativas, o que exige um poder estatal que redistribua dinheiro dos ganhadores aos perdedores, usando para isso impostos e subsídios e/ou crédito"(SINGER, 2002,p. 10).

6 Omitem, portanto que, os "capitalistas não partilham o mundo levados por uma particular perversidade, mas porque o grau de concentração a que se chegou os obriga a seguir esse caminho para obterem lucros; e repartem-no 'segundo o capital', 'segundo a força'; qualquer outro processo de partilha é impossível no sistema da produção mercantil e no capitalismo"(LÊNIN, 1986, p. 631).

7 Essa discussão tem no seu bojo distintas análises superficiais da realidade capitalista. Dentre estas, poder-se-ia destacar a ideologia presente na categoria 'alternativo', conforme demonstra criticamente Iamamoto (2004), ou nas ficções disseminadas pelos representantes do 'trabalho imaterial', segundo explicitaLessa (2004).

8 Afirmação que não passa de mistificação ideológica como demonstram: Tavares (2004); Montaño (2005, 1999); Lima (1998, 2003); Germer(2006).

9 "Trata-se do período histórico em que ao capitalismo concorrencial sucede o capitalismo dos monopólios, articulando o fenômeno global que, especialmente a partir dos estudos lenineanos, torna-se conhecido como o 'estágio imperialista"'(PAULONETTO, 2005,p.19).

10 Diferentemente dessa postura mistificadora, uma importante discussão concreta sobre a relação entre autonomia das organizações produtivas e a planificação do mercado na fase de transição ao comunismo, pode serencontradaem: Guevara, Mandele Bettelheim(2005).

11 Sobre as distinções entre as categorias singular, particular e universal no pensamento marxista, ver: Lukács (1978).

12 Retoma-se, assim, a velha máxima apontada por Marx contra Proudhon: a necessidade de apelar para os corações e bolsos dos burgueses (MARX, 2001). 
13 Um exemplo atual dessa dinâmica são os diversos selos de certificação ISO (International Organization for Standardization).

14 Um importante texto que se propõe a desmistificar a relação complementarentre 'economia solidária' e classe trabalhadora éodeGermer(2006).

15 "A consciência reificada deve permanecer prisioneira, na mesma medida e igualmente sem esperança, nos extremos do empirismo grosseiro e do utopismo abstrato. Desse modo, ou a consciência se torna um espectador inteiramente passivo do movimento das coisas conforme a lei, no qual não pode intervir sob nenhuma circunstância, ou se considera como umpoder capaz de dominar ao seu bel-prazer-subjetivamente - o movimento das coisas, em si destituído de sentido" (LUKÁCS, 2003,p. 185).

\section{Henrique André Ramos Wellen}

Doutorando em Serviço Social na Escola de Serviço Social na Universidade Federal do Rio de Janeiro (UFRJ)

Orientador: Carlos Eduardo Montaño Barreto

\section{UFRJ}

Escola de Serviço Social

Avenida Pasteur, 250 - Fundos

Prédio da ESS

Urca

Rio de Janeiro - Rio de Janeiro

CEP: 22290-902 